\title{
Chemical, physicochemical, microbiological and sensory characterization of cow and buffalo ghee
}

\author{
Carolina PENA-SERNA ${ }^{1 *}$ (D), Luis Fernando RESTREPO-BETANCUR ${ }^{2}$
}

\begin{abstract}
Due to the increasing consumption of ghee in the Western countries, a complete characterization of buffalo and cow ghee was performed to complement and update the available literature. Ghee is a lipophilic dairy product with $98.9 \%$ lipids, $0.3 \%$ water and less than $0.9 \%$ nonfat solids. Fatty acids are the major lipid fraction and represent $85.1 \%$ and $83.65 \%$ for buffalo and cow ghee, respectively. More than $52 \%$ of the fatty acids were saturated, and palmitic (24-28.8\%), stearic (9.4-14\%) and myristic $(8.5-10 \%)$ acids were predominant. Monounsaturated fatty acids were approximately $23.8 \%$ and the major component was oleic acid. Polyunsaturated fatty acid content was $2.45 \%$ (buffalo) and $4 \%$ (cow). The vaccenic acid (2.18\%) and the conjugated linoleic acid (CLA cis-9, trans-11) with a concentration of $0.77 \%$ in buffalo and $1 \%$ in cow ghee, were the main ruminant trans fatty acids. The physicochemical and microbiological characteristics of cow and buffalo ghee complied with the literature and national regulation. Finally, the sensory profile of buffalo and cow ghee was defined with a predominantly lactic odor, followed by cooked and fatty notes. The taste was characterized as fatty, lactic, sweet and cooked; and the texture was described as fatty with fatty mouthfeel, lumpy and greasy notes.
\end{abstract}

Keywords: sensory profile; human nutrition; clarified butter; conjugated linoleic acid; ruminant trans fatty acids.

Practical Application: This study intends to be a basis for the analysis and discussion of ghee intake and the benefits and risks to human health.

\section{Introduction}

Ghee also known as clarified butter, is an ancient dairy product prepared by heating milk, cream or butter over $100^{\circ} \mathrm{C}$ to evaporate water and precipitate the nonfat solids (Andrewes, 2012; Antony et al., 2018; Sharma et al., 2010; Sieber, 2005). Ghee is widely produced and consumed in India, Sudan, Ethiopia and the Middle East (Antony et al., 2018; El-Shourbagy \& El-Zahar, 2014; Kumar et al., 2000); nevertheless, in the last decade, the American continent, with USA, Argentina and Paraguay, as the main producers, has increased the production of cow ghee between 3000 and 12000 tons per year (Food and Agriculture Organization of the United Nations, 2019). In the same way, Western countries have displayed increasing ghee intake (Antony et al., 2018) as a result of the globalization process as well as the replacement of the consumption of margarine due to the high content of industrial trans fatty acids (iTFA). According to the current scientific evidence, iTFA has exhibited a higher negative impact on cardiovascular disease, diabetes and even depression than saturated fatty acids (Ford et al., 2016; Mozaffarian et al., 2009; Park, 2009; Vučić et al., 2015). Galvín et al. (2016) reported that one gram of iTFA has 15 -fold higher risk of coronary disease than one gram of saturated fatty acids.

According to literature, ghee is a lipophilic product with 99-99.5\% lipids from which $46-47.8 \%$ is saturated fat, $36 \%$ monounsaturated and $18 \%$ polyunsaturated (Sharma et al., 2010; Sserunjogi et al., 1998). Ghee is also considered a good source of lipophilic vitamins (Upadhyay et al., 2017a), especially vitamin A and E (Antony et al., 2018), and conjugated linoleic acid - CLA (Food and Agriculture Organization of the United Nations, 2013; Mehta et al., 2015; Upadhyay et al., 2017b), which is a ruminant trans fatty acid (rTFA) that has exhibited health benefits, both in vitro and in vivo (Galvín et al., 2016), such as anti-obesity, anti-carcinogenic, anti-atherogenic, anti-diabetic, anti-mutagenic, anti-hypertensive, immunomodulatory, apoptotic and osteosynthetic (Hur et al., 2017; Koba \& Yanagita, 2014; Serafeimidou et al., 2013; Yang et al., 2015).

Due to the lipophilic composition of ghee, as well as the scientific evidence of the association between fats intake and the risk of coronary disease (Ford et al., 2016; Galvín et al., 2016; Vučić et al., 2015), and the increasing trend on ghee consumption exhibited by the Western countries (Antony et al., 2018), the current study aims to characterize buffalo and cow ghee in terms of the proximate composition, and the physicochemical, microbiological and sensory characteristics to be a basis for the analysis and discussion regarding ghee consumption and the benefits or risks to human health and nutrition.

\section{Materials and methods}

Three batches of each type of ghee were produced using $100 \mathrm{~L}$ of milk. Three samples of each batch, for a total of nine samples, were taken and analyzed. 


\subsection{Materials}

Buffalo milk was collected from Vegas de la Clara farm located in Gomez Plata, Antioquia, Colombia, and cow milk was obtained from La Montaña farm located in San Pedro de los Milagros, Antioquia, Colombia. Both farms are property from the University of Antioquia. Chemicals for chromatographic analyses, cis/trans linoleic acid methyl ester mix, FAME mix food industry of 37 components fatty acids from C4 to C24 (Restek), triglyceride triundecanoin, hexane, boron trifluoride and $\mathrm{NaOH} /$ methanol were purchased from Millipore-Sigma. Chemical reagents and solvents for physicochemical and proximate composition $(\mathrm{NaOH}, \mathrm{HCl}$, ether, ethanol, $\mathrm{KOH}, \mathrm{KI}$, sodium thiosulfate and Wij's solution) were of analytical grade and were purchased from Millipore-Sigma.

\subsection{Extraction of cream and butter production}

Buffalo or cow milk (100 L) was warmed at $40 \pm 2{ }^{\circ} \mathrm{C}$ and then skimmed using a Slavic beauty centrifugal cream separator. Cream was pasteurized at $85 \pm 3{ }^{\circ} \mathrm{C}$ for $10 \mathrm{~min}$ and stored at $4^{\circ} \mathrm{C}$ for $24 \mathrm{~h}$. Buffalo and cow butters were obtained by churning cold cream $\left(<10^{\circ} \mathrm{C}\right)$ in a butter-making machine and then, these two were packaged in vacuum packaging and stored at $4{ }^{\circ} \mathrm{C}$ until ghee production. Both processes were carried out at the dairy plant located at Vegas de la Clara farm.

\subsection{Ghee production}

Ghee was prepared by the creamery butter (CB) method, where the butter was heated at a temperature between $85-100{ }^{\circ} \mathrm{C}$ with periodic stirring until water evaporation and the sedimentation and development of golden-colored nonfat solids (NFS). Thereafter, the heating temperature increased to $113{ }^{\circ} \mathrm{C}$ for $3 \mathrm{~min}$, and finally, the ghee was cooled to $60^{\circ} \mathrm{C}$, filtered, packed in glass containers with metal lids and stored in darkness at room temperature $\left(24 \pm 2{ }^{\circ} \mathrm{C}\right)$ until analytical procedures. The production of ghee was also performed at the dairy plant located in Vegas de la Clara farm.

\subsection{Chemical analyses}

Ghee samples were analyzed by gas chromatography to identify and quantify the fatty acid profile. Chemical analyses were performed to assess proximate composition and physicochemical characteristics of ghee.

\section{Lipid extraction and methyl derivative preparation}

150-200 mg of ghee sample was weighed and extracted with $50 \mathrm{~mL}$ of hexane using the Soxtec 2050 equipment following the established program (20 min boiling, $40 \mathrm{~min}$ rinsing, $10 \mathrm{~min}$ recovery and $10 \mathrm{~min}$ pre-drying) and then hexane was evaporated at $70{ }^{\circ} \mathrm{C}$. The extracted lipid material was combined with $1 \mathrm{~mL}$ of the internal standard, triundecanoin $(>98 \%)$ with concentration of $5 \mathrm{mg} / \mathrm{mL}$, and $4 \mathrm{~mL}$ of $0.5 \mathrm{M} \mathrm{NaOH} /$ methanol. The mixture was heated to $100{ }^{\circ} \mathrm{C} / 10 \mathrm{~min}$ and $5 \mathrm{~mL}$ of $7 \%$ boron trifluoride in methanol was added and heated for another $2 \mathrm{~min}$. Then, $4 \mathrm{~mL}$ of hexane was added, and heated for $1 \mathrm{~min}$. Thereafter, it was cooled to room temperature and a saturated sodium chloride solution was added. The upper layer that contained the fatty acid methyl ester derivative (FAME) was transferred to an Eppendorf vial and stored at $-18{ }^{\circ} \mathrm{C}$ until chromatographic analyses.

\section{FAME identification and quantification}

The saturated (SFA), monounsaturated (MUFA) and polyunsaturated (PUFA) fatty acids contained in buffalo and cow ghee were assessed by a gas chromatograph with flame ionization detector-GC/FID (Agilent Mod. 7890B) equipped with a TR-CN100 column $(60 \mathrm{~m} \times 250 \mu \mathrm{m}$ ID $\times 0.20 \mu \mathrm{m}$ film thickness). GC/FID conditions were as follows: injector temperature $260{ }^{\circ} \mathrm{C}$, detector temperature $300^{\circ} \mathrm{C}$, split ratio $100: 1$, helium carrier gas with a flow rate of $1.1 \mathrm{~mL} / \mathrm{min}$, injection volume $1 \mu \mathrm{L}$ and temperature program: $90^{\circ} \mathrm{C} / 7 \mathrm{~min}$ followed by heating at $5{ }^{\circ} \mathrm{C} / \mathrm{min}$ to $240{ }^{\circ} \mathrm{C} / 15 \mathrm{~min}$. GC-FID conditions for ruminant trans fatty acids (rTFA) quantification were as follows: injector temperature $220{ }^{\circ} \mathrm{C}$, detector temperature $250{ }^{\circ} \mathrm{C}$, split ratio $50: 1$, helium carrier gas with a flow rate of $1 \mathrm{~mL} / \mathrm{min}$, injection volume $1 \mu \mathrm{L}$ and the temperature program $170{ }^{\circ} \mathrm{C} / 5 \mathrm{~min}$ followed by heating at $5^{\circ} \mathrm{C} / \mathrm{min}$ to $240{ }^{\circ} \mathrm{C} / 5 \mathrm{~min}$. FAME identification was performed by comparing the retention times with those of chromatographic standards, and quantification was carried out according to the standard method 996.06 (Association of Official Analytical Chemists, 2016).

\section{Proximate composition}

The protein content of cow and buffalo ghee was assessed following the Kjeldahl standard method 954.01 (Association of Official Analytical Chemists, 2016) converting the nitrogen to protein using the factor 6.38 and the water content was determined by drying the samples at $105 \pm 1{ }^{\circ} \mathrm{C}$ to constant weight according to the standard method 920.116 (Association of Official Analytical Chemists, 2016). The ash concentration was quantified by calcination at $550{ }^{\circ} \mathrm{C}$ until the residue was white following the standard method 920.117 (Association of Official Analytical Chemists, 2016). Lipid concentration was measured according to the direct method used for butter, standard method 938.06 (Association of Official Analytical Chemists, 2016), and the energy content was evaluated by an automated adiabatic calorimeter.

\section{Physicochemical characteristics}

The acid, peroxide, saponification and iodine values of cow and buffalo samples were assessed. The acid value was determined by mixing $20 \mathrm{~g}$ of ghee and $50 \mathrm{~mL}$ of neutralized ethanol, then the mixture was titrated against $0.1 \mathrm{~N} \mathrm{NaOH}$ according to the standard method 940.28 (Association of Official Analytical Chemists, 2016). The peroxide value was assessed by mixing $5 \mathrm{~g}$ of ghee, $0.5 \mathrm{~mL}$ of saturated KI solution and $30 \mathrm{~mL}$ of a solvent mixture of acetic acid and chloroform (3:2), followed by titration against $0.1 \mathrm{~N} \mathrm{Na}_{2} \mathrm{~S}_{2} \mathrm{O}_{3}$ using $1 \%$ starch as indicator according to standard method 965.33 (Association of Official Analytical Chemists, 2016). The saponification value was quantified following the standard method 920.160 (Association of Official Analytical Chemists, 2016). $5 \mathrm{~g}$ of ghee and $50 \mathrm{~mL}$ of alcoholic $\mathrm{KOH}$ solution were combined in a flask, thereafter, 
the flask was connected to a reflux condenser and boiled for an hour, then, the cooled mixture was titrated against $0.5 \mathrm{~N} \mathrm{HCl}$ using phenolphthalein as indicator. Finally, the iodine value was measured according to the Wijs method 920.159 (Association of Official Analytical Chemists, 2016).

\subsection{Microbiological analyses}

The mesophilic aerobic bacteria and Staphylococcus coagulase positive were quantified (CFU/g), the total and fecal coliforms were estimated (MPN/g), and Salmonella sp. and Listeria monocytogenes were detected. The mesophilic aerobic bacteria were enumerated on plate count agar incubated aerobically at $30^{\circ} \mathrm{C}$ for $72 \mathrm{~h}$. Staphylococcus coagulase + were enumerated on Baird-Parker agar with egg yolk tellurite incubated at $36^{\circ} \mathrm{C}$ for $48 \mathrm{~h}$. Coliform bacteria were estimated on Fluorocult ${ }^{\oplus}$ Brillant Green 2\%-Bile (BRILA) broth, incubated at $37^{\circ} \mathrm{C}$ for $24-48 \mathrm{~h}$. Tubes were checked under UV light $(\lambda=366 \mathrm{~nm})$, and when observed a positive response, the fecal coliforms were confirmed by adding KOVACS indole reagent until the appearance of a red ring. The presence of $L$. motocytogenes was determined in $25 \mathrm{~g}$ of sample incubated on VIDAS ${ }^{\circledast}$ LMX broth at $37^{\circ} \mathrm{C}$ for $26-30 \mathrm{~h}$, and Salmonella sp. was detected in $25 \mathrm{~g}$ of ghee sample according to the culture enrichment procedure 6579-1 (International Organization for Standardization, 2017).

\subsection{Sensory analysis}

Buffalo and cow ghees were evaluated using the method of sensory profile by a multidimensional approach (Instituto Colombiano de Normas Técnicas y Certificación, 1996) which is a descriptive analysis widely used in dairy products (Kwak et al., 2016; Silva et al., 2018; Torres et al., 2017). Sensory tests were performed after the confirmation of the microbiological safety of ghee samples. The sensory evaluation was carried out by a trained panel of six members (both sexes, ages ranging between 25 and 55 years old) in the sensory room of the Nutrition and Diet School from University of Antioquia (Medellin, Colombia). Ghee samples were placed in plastic cups coded with random 3 -digit codes and presented in sequential order to panelists under white fluorescent light at room temperature $24 \pm 2{ }^{\circ} \mathrm{C}$ and relative humidity of $48 \pm 1 \%$. First, the panelists identified and selected the descriptors for establishing the sensory profile of ghee, and thereafter, the intensities of the descriptors were evaluated in a scale from 0 to 5 (where $0=$ low and $5=$ high) and the global quality was assessed in a scale from 1 to 3 (where $1=$ low and $3=$ high). The descriptors were established for the sensory attributes of appearance, odor, flavor and texture.

\subsection{Statistical analyses}

The data were subjected to multivariate analysis of variance - MANOVA in order to evaluate the overall statistical difference between ghee samples considering all the correlated response variables. Thereafter, the analysis of canonical correlation - ACC allowed us to establish multidimensional differences between cow and buffalo ghee. The biplot analysis based on Pythagorean dissimilarities and central transformation was also carried out. The statistical analyses were performed with the free software SAS University edition and R-project $\mathrm{v}$ 3.4.4.

\section{Results and discussion}

A complete characterization of buffalo and cow ghee was performed. The analyses included the evaluation of the proximate composition and the fatty acid profile, as well as the physicochemical, microbiological and sensory characteristics of ghee.

The major component of ghee samples was the lipid fraction comprising approximately $98.9 \%$ of the product, less than $0.9 \%$ nonfat solids and $0.3 \%$ of moisture. Buffalo and cow ghees exhibited highly statistical differences $(p<0.0001)$ on the ash content while the protein, moisture, energy and lipid compositions were similar ( $p>0.0001)$ in both samples (Table 1). When all the nutritional components were evaluated simultaneously, the analysis of the canonical correlation (ACC) allowed to establish that buffalo and cow ghee displayed similar gross composition. According to Ganguli \& Jain (1972) and Sserunjogi et al. (1998), the moisture and lipid content of ghee should be below $0.3 \%$ and above $96 \%$, respectively; thus, the proximate composition of cow and buffalo samples complied with the reported values.

Moreover, ghee samples displayed no oxidation after the production since the peroxide value was 0 meq-g/kg; nonetheless, cow ghee showed higher acid value than buffalo ghee (Table 1). Based on that result, it is likely that cow ghee undergoes higher oxidation and rancidity throughout the time. On the other hand, the saponification value of the samples exhibited no difference which means that the molecular weight of the fatty acids that are present in the buffalo and cow ghee was similar and corresponded to long-chain fatty acids above 14-carbons as can be seen in Table 2. According to the iodine value, cow ghee contained a higher amount of unsaturated fatty acids than the buffalo ghee. This result was also confirmed with the higher concentration of MUFA and PUFA contained in cow ghee $(28.31 \%)$ regarding $25.19 \%$ exhibited by the buffalo sample (Table 2). The MANOVA analysis that was performed to the physicochemical characteristics of the two products showed highly statistical difference $(\mathrm{p}<0.0001)$ and the ACC analysis that was applied for evaluating simultaneously all physicochemical characteristics of ghee samples indicated that buffalo and cow samples displayed differences.

Sserunjogi et al. (1998) reported a maximum concentration of free fatty acids of $0.3 \%$ and a peroxide value below 1 . Similarly,

Table 1. Proximate composition and physicochemical characteristics of buffalo and cow ghee.

\begin{tabular}{lcc}
\hline \multicolumn{1}{c}{ Component/Characteristic } & Buffalo ghee & Cow ghee \\
\hline Moisture (\%) & $0.3 \pm 0.016 \mathrm{a}$ & $0.3 \pm 0.022 \mathrm{a}$ \\
Lipid (\%) & $98.9 \pm 0.50 \mathrm{a}$ & $98.8 \pm 0.80 \mathrm{a}$ \\
Protein (\%) & $0.78 \pm 0.026 \mathrm{a}$ & $0.81 \pm 0.045 \mathrm{a}$ \\
Ash $(\%)$ & $0.03 \pm 0.002 \mathrm{~b}$ & $0.09 \pm 0.028 \mathrm{a}$ \\
Energy $(\mathrm{kcal} / \mathrm{kg})$ & $9305 \pm 230.5 \mathrm{a}$ & $9483 \pm 44.5 \mathrm{a}$ \\
Acid value $(\mathrm{mg} \mathrm{NaOH} / \mathrm{g})$ & $0.03 \pm 0.01 \mathrm{~b}$ & $0.21 \pm 0.02 \mathrm{a}$ \\
Free fatty acids $(\%)$ & $0.01 \pm 0.005 \mathrm{~b}$ & $0.1 \pm 0.01 \mathrm{a}$ \\
Saponification value $(\mathrm{mg} \mathrm{KOH} / \mathrm{g})$ & $233.9 \pm 38.5 \mathrm{a}$ & $217 \pm 9.2 \mathrm{a}$ \\
Iodine value $(\mathrm{g}$ iodine $/ 100 \mathrm{~g})$ & $22.6 \pm 1.58 \mathrm{~b}$ & $50.6 \pm 1.59 \mathrm{a}$ \\
\hline Data are expressed as mean \pm standard deviation. Different letter within a raw indicates \\
statistically difference $(\mathrm{p}<0.05)$.
\end{tabular}


Table 2. Fatty acid profile of buffalo and cow ghee.

\begin{tabular}{crr}
\hline Fatty acid & Buffalo ghee $(\%)$ & Cow ghee $(\%)$ \\
\hline C4:0 & $1.96 \pm 0.001 \mathrm{a}$ & $1.78 \pm 0.004 \mathrm{~b}$ \\
C6:0 & $0.86 \pm 0.002 \mathrm{~b}$ & $1.44 \pm 0.001 \mathrm{a}$ \\
C8:0 & $0.41 \pm 0.002 \mathrm{~b}$ & $0.99 \pm 0.001 \mathrm{a}$ \\
C10:0 & $0.86 \pm 0.002 \mathrm{~b}$ & $2.55 \pm 0.001 \mathrm{a}$ \\
C12:0 & $2.04 \pm 0.003 \mathrm{~b}$ & $3.15 \pm 0.001 \mathrm{a}$ \\
C13:0 & $0.06 \pm 0.002 \mathrm{~b}$ & $0.09 \pm 0.001 \mathrm{a}$ \\
C14:0 & $8.54 \pm 0.003 \mathrm{~b}$ & $10.30 \pm 0.004 \mathrm{a}$ \\
C14:1 & $0.35 \pm 0.003 \mathrm{~b}$ & $0.94 \pm 0.032 \mathrm{a}$ \\
C15:0 & $1.03 \pm 0.003 \mathrm{a}$ & $0.97 \pm 0.001 \mathrm{a}$ \\
C16:0 & $28.84 \pm 0.009 \mathrm{a}$ & $24.03 \pm 0.015 \mathrm{~b}$ \\
C16:1 & $1.13 \pm 0.011 \mathrm{a}$ & $1.18 \pm 0.006 \mathrm{a}$ \\
C17:0 & $0.79 \pm 0.004 \mathrm{a}$ & $0.49 \pm 0.009 \mathrm{~b}$ \\
C18:0 & $14.04 \pm 0.007 \mathrm{a}$ & $9.36 \pm 0.007 \mathrm{~b}$ \\
C18:1 & $18.64 \pm 0.213 \mathrm{~b}$ & $20.04 \pm 0.013 \mathrm{a}$ \\
C18:1 t6 & $0.17 \pm 0.006 \mathrm{a}$ & $0.00 \pm 0.000 \mathrm{~b}$ \\
C18:1 t9 & $0.22 \pm 0.005 \mathrm{a}$ & $0.00 \pm 0.000 \mathrm{~b}$ \\
C18:1 t11 & $2.23 \pm 0.006 \mathrm{a}$ & $2.13 \pm 0.009 \mathrm{a}$ \\
C18:2 & $0.92 \pm 0,011 \mathrm{~b}$ & $1.64 \pm 0.001 \mathrm{a}$ \\
C18:2 c9, t12 & $0.00 \pm 0.000 \mathrm{~b}$ & $0.13 \pm 0.001 \mathrm{a}$ \\
C18:2 t9, c12 & $0.00 \pm 0.000 \mathrm{~b}$ & $0.17 \pm 0.003 \mathrm{a}$ \\
C18:2 c9, t11 & $0.77 \pm 0.004 \mathrm{~b}$ & $1.00 \pm 0.003 \mathrm{a}$ \\
C18:3 & $0.48 \pm 0.005 \mathrm{~b}$ & $0.66 \pm 0.001 \mathrm{a}$ \\
C18:3 t9, t12, t15 & $0.00 \pm 0.000 \mathrm{~b}$ & $0.01 \pm 0.001 \mathrm{a}$ \\
C18:3 t9, c12, c15 & $0.09 \pm 0.002 \mathrm{~b}$ & $0.12 \pm 2 \times 10^{-4} \mathrm{a}$ \\
C20:0 & $0.23 \pm 0.003 \mathrm{a}$ & $0.12 \pm 0.003 \mathrm{~b}$ \\
C20:3 n-6 & $0.06 \pm 0.001 \mathrm{~b}$ & $0.07 \pm 0.001 \mathrm{a}$ \\
C20:3 n-3 & $0.00 \pm 0.000 \mathrm{~b}$ & $0.02 \pm 0.001 \mathrm{a}$ \\
C20:4 & $0.07 \pm 0.002 \mathrm{~b}$ & $0.11 \pm 8 \times 10^{-4} \mathrm{a}$ \\
C20:5 & $0.06 \pm 0.001 \mathrm{~b}$ & $0.07 \pm 0.001 \mathrm{a}$ \\
C22:0 & $0.09 \pm 0.001 \mathrm{a}$ & $0.04 \pm 0.001 \mathrm{~b}$ \\
C22:6 & $0.00 \pm 0.000 \mathrm{~b}$ & $0.03 \pm 0.003 \mathrm{a}$ \\
C23:0 & $0.10 \pm 0.002 \mathrm{a}$ & $0.02 \pm 3 \times 10^{-4} \mathrm{~b}$ \\
C24:0 & $0.08 \pm 0.002 \mathrm{a}$ & $0.03 \pm 0.001 \mathrm{~b}$ \\
SFA & 59.91 & 55.34 \\
MUFA cis & 20.12 & 22.16 \\
PUFA & 2.62 & 4.02 \\
\hline FA & 2.45 & 85 \\
\hline
\end{tabular}

Data are expressed in \% (g/100 g dry lipids) and as mean \pm standard deviation. Different letter within a raw indicates statistically difference $(\mathrm{p}<0.05)$. SFA: saturated fatty acid, MUFA: monounsaturated fatty acid, MUFA cis: MUFA with cis configuration, MUFA trans: MUFA with trans configuration, PUFA: polyunsaturated fatty acid, FA: total fatty acids.

Ganguli \& Jain (1972) described the saponification value of ghee above 220 and the iodine value between 26 and 38. Regarding the content of free fatty acids and the peroxide value, the buffalo and cow ghees are in accordance with the values reported in the literature; nonetheless, they displayed iodine values outside the reported range and as mentioned above, it was a consequence of the higher concentration of unsaturated fatty acids contained in cow ghee and the lower content in the buffalo sample. Likewise, cow ghee exhibited lower saponification number than informed by Ganguli \& Jain (1972). Despite of the differences exhibited by the ghee samples evaluated in this study and the reported values for the iodine and saponification indices, the authors consider that such variation cause no negative effect on the quality of ghee, and it is likely a result of a different fatty acid profile produced by the animal feeding (Ferlay et al., 2017).

Due to triacylglycerols (TAG) are the main fraction of the lipids contained in bovine milk, and comprise approximately $98 \%$ of the lipids (Liu et al., 2018), TAG are also the dominant component in ghee (Antony et al., 2018). The main element of triacylglycerol is the fatty acid, and their concentration in buffalo and cow ghee were $85.1 \%$ and $83.65 \%$, respectively. Saturated fatty acids (SFA) were predominant and comprised above $55 \%$ of the total fatty acids, followed by approximately $23.5 \%$ of monounsaturated fatty acids (MUFA) and polyunsaturated fatty acids (PUFA) up to $4 \%$ (Table 2). The MANOVA analysis established a highly statistical difference $(p<0.0001)$ between the fatty acid profiles of the two products. Moreover, when all the SFAs were evaluated simultaneously, the ACC established that buffalo and cow ghee had different SFA profiles. Similarly, the polyunsaturated and monounsaturated fatty acids exhibited differences between samples.

Buffalo and cow ghee exhibited higher SFA content than the reported by Dwivedi et al. (2002) and Sserunjogi et al. (1998) with SFA concentrations of $47.8 \%$ and $46 \%$, respectively. Nonetheless, it was similar to the proportion determined by Manickavasagan \& Al-Sabahi (2014) of 59\%.

For several years, margarine was recognized by the scientific community as well as the consumers, as a healthier source of lipids due to the higher PUFA and lower SFA content than that in butter. Despite that, a study performed by Vučić et al. (2015) on 13 Serbian margarines showed SFA contents between $22.76 \%$ and $51.17 \%$. Hence, margarines might contain similar or even higher concentration of SFA than that in butter and/or ghee. Some studies have reported a content of MUFA and PUFA in ghee of $32.8 \%$ and $2.9 \%$ (Manickavasagan \& Al-Sabahi, 2014) and $36 \%$ and 5\% (Sserunjogi et al., 1998), respectively. Both studies displayed higher MUFA and PUFA content than the ghee samples that were evaluated in this study (Table 2).

Palmitic - C16:0 (24-28\%), stearic - C18:0 (9-14\%) and myristic - C14:0 (8-10\%) acids were the three main SFA contained in buffalo and cow ghee, and these were also reported by Antony et al. (2018). Oleic acid - C18:1 (18.5-20.7\%) was the major MUFA while linoleic acid - C18:2 (0.8-1.6\%) was the higher PUFA contained in the samples (Table 2). The concentration of myristic, palmitic, oleic and linoleic acids that were found in the ghee samples were lower than those reported by Manickavasagan \& Al-Sabahi (2014) while stearic and a-linoleic acid (C18:3) contents were higher. Finally, as ghee is a dairy product obtained from ruminants, the trans fatty acids (TFA) contained in ghee are a consequence of the hydrogenation of unsaturated fatty acids produced by rumen bacteria, thus, they are ruminant TFA (rTFA). According to some epidemiological studies, rTFA have exhibited no negative effect on coronary heart disease risk factors (Ferlay et al., 2017; Gebauer et al., 2011; Jakobsen et al., 2006) unlike the industrially TFA (iTFA) that are contained for instance, in margarine (Ganguli \& Jain, 1972; Stender et al., 2008). Buffalo and cow ghees displayed a concentration of vaccenic acid (C18:1 t-11) above $1.7 \%$ and up to $1 \%$ of conjugated linoleic 
acid - CLA (C18:2 c-9, t-11), which were the most abundant rTFA (Table 2). The CLA isomer C18:2 c-9, t-11 has exhibited health benefits, both in vitro and in vivo (Galvín et al., 2016), such as anti-carcinogenic, anti-atherogenic, anti-diabetic, anti-mutagenic, anti-hypertensive, immunomodulatory, apoptotic and osteosynthetic effects (Hur et al., 2017; Koba \& Yanagita, 2014; Serafeimidou et al., 2013; Yang et al., 2015). Moreover, the CLA content exhibited by the ghee samples was at least 1.3-fold higher to that reported for meat, seafood, other dairy products, animal fats and vegetable oils with CLA concentration up to $0.56 \%$ (Koba \& Yanagita, 2014).

Currently, Colombia has no microbiological regulation for ghee, as well as there is no international microbiological standard from Codex Alimentarius; hence, microbiological characterization of ghee (Table 3) was based on butter. According to Colombian regulation, Resolución 2310/1986

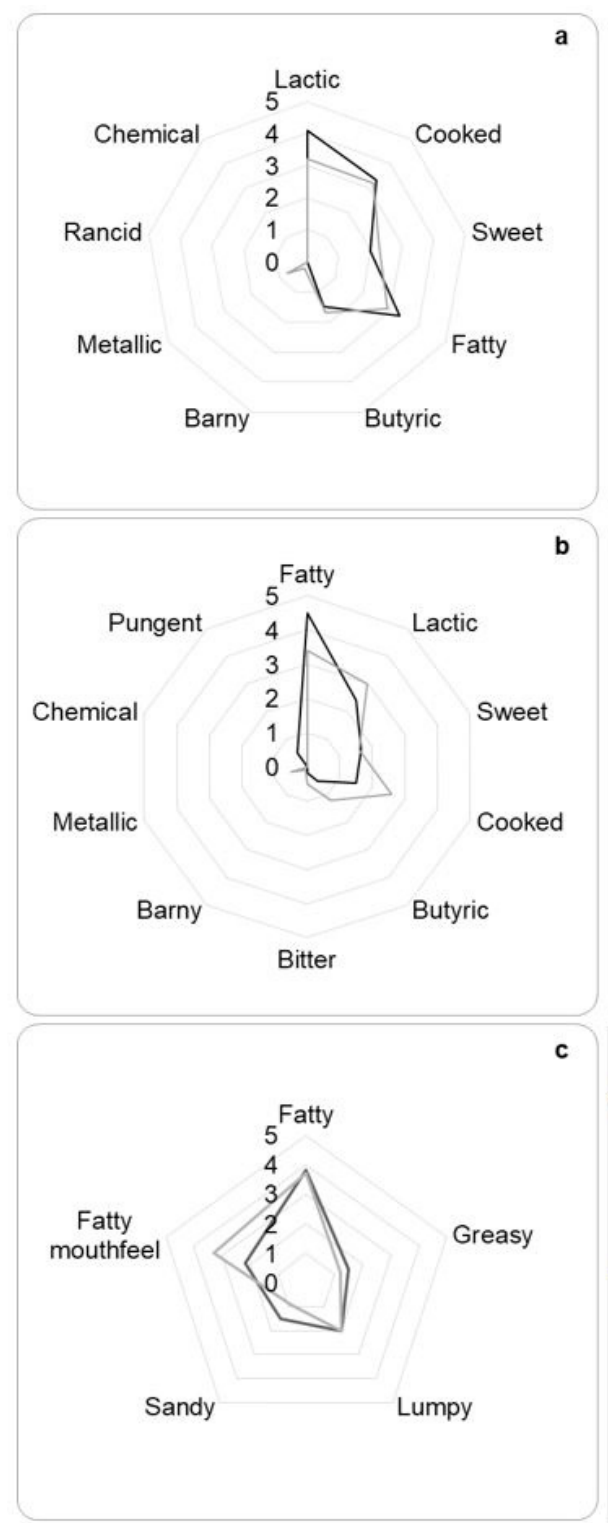

(Colombia, 1986), butter must comply with total coliform below $150 \mathrm{MPN} / \mathrm{g}$, fecal coliform < $3 \mathrm{MPN} / \mathrm{g}$, Staphylococcus coagulase positive $<200 \mathrm{CFU} / \mathrm{g}$ and no presence of Salmonella. Due to Listeria monocytogenes is a pathogenic bacterium, its presence was also verified. As observed in Table 3, cow ghee exhibited higher content of microorganisms than buffalo ghee; nonetheless, ghee

Table 3. Microbiological quality of buffalo and cow ghee.

\begin{tabular}{lcc}
\hline \multicolumn{1}{c}{ Microorganism } & Buffalo ghee & Cow ghee \\
\hline Mesophilic aerobic bacteria (CFU/g) & $<1$ & $<10$ \\
Total coliform (MPN/g) & $<3$ & 3.6 \\
Faecal coliform (MPN/g) & $<3$ & $<3$ \\
Staphylococcus coagulase + (CFU/g) & $<10$ & $<100$ \\
Salmonella sp. & Absent & Absent \\
Listeria monocytogenes & Absent & Absent \\
\hline
\end{tabular}

CFU: colony-forming unit, MPN: most probable number.
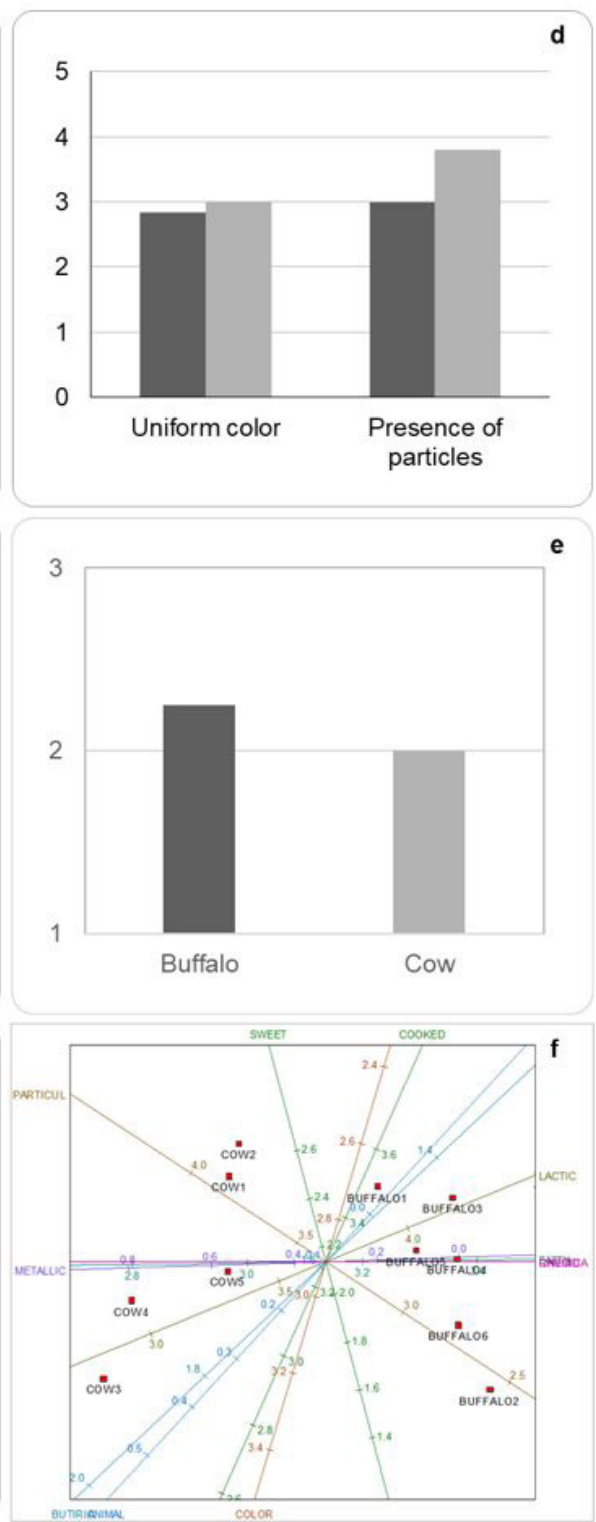

Figure 1. Sensory profile of ghee ( $\bullet$ buffalo, $\bullet$ cow) for the attributes of (a) odor; (b) taste; (c) texture; (d) appearance; (e) global quality; (f) Biplot analysis of sensory evaluators. 
samples complied with national regulation for butter, and thus, both products were claimed as safe for the sensory evaluation.

The sensory profile of buffalo and cow ghees were established by a trained panel of six members and the results are presented in Figure 1. To date, and to the best of our knowledge, no study has been accomplished on the organoleptic characteristics of ghee.

The statistical analysis MANOVA indicated a highly statistical difference $(\mathrm{p}<0.0001)$ between the sensory profiles of cow and buffalo ghees. According to the results, the odor profile of ghee was defined as predominantly lactic followed by cooked and fatty odor with sweet and butyric notes (Figure 1a). The lactic odor was perceived in a higher proportion in buffalo than in cow ghee. The taste profile was characterized mainly by fatty followed by lactic, cooked and sweet notes (Figure 1b). Both samples displayed differences mainly in the cooked and fatty descriptors.

The texture profile was described as predominantly fatty, and exhibited fatty mouthfeel, lumpy and greasy texture. The cow and buffalo samples displayed also slight sandy texture (Figure 1c); nonetheless, cow ghee displayed the highest presence of particles (Figure 1d). The texture profile of cow and buffalo samples showed high difference in the fatty mouthfeel as well as the sandiness. The global quality of buffalo ghee was evaluated with a higher score by the panel (Figure 1e) due to the best flavor of the sample. According to the biplot analysis (Figure 1f), the sensory evaluators estimated more accurately buffalo ghee than cow ghee since the latter exhibited the highest dispersion.

The sensory profile of cow and buffalo ghees determined in this study may be a reliable tool for the dairy industry of the Western countries that are currently standardizing the production process. The organoleptic profile allows the dairy industry to adjust the process conditions as well as to establish the physicochemical and proximate characteristics of milk that are required in order to guarantee the best quality of the final product (Torres et al., 2017).

In the same way, the authors consider that further affective analyses with consumers may be a good alternative to study their product perception (Esmerino et al., 2017; Pinto et al., 2019). Qualitative techniques will allow the dairy industry to improve and/or adjust sensory attributes of ghee according to customers' preferences and needs (Oliveira et al., 2017). Moreover, they will also promote the dairy product among new users, enabling the growth of the dairy sector (Esmerino et al., 2017; Pinto et al., 2019).

\section{Conclusions}

Despite the existence and consumption of ghee for a long time, the scientific literature is limited and dated. Based on that, as well as the increasing trend exhibited by the Western countries on the product intake, the current study performed a complete characterization of buffalo and cow ghee. Ghee exhibited $0.3 \%$ water and $98.9 \%$ lipids, where triacylglycerols were the main lipid component. Saturated fatty acids (SFA) were present over $52 \%$ of the total fatty acid content, followed by monounsaturated (MUFA) and polyunsaturated (PUFA) fatty acids. Buffalo ghee displayed more SFA content while cow ghee showed higher MUFA and PUFA concentration. The main fatty acids contained in ghee were palmitic, oleic, stearic and myristic acids. Vaccenic acid (2.18\%) and conjugated linoleic acid $(0.77 \%$ in buffalo and $1 \%$ in cow ghee) were the main ruminant trans fatty acids. The physicochemical and microbiological quality of buffalo and cow ghees were in accordance with literature and/or national or international regulation. The sensory profile of buffalo and cow ghee was characterized by an odor described as predominantly lactic, cooked and fatty, while the taste was defined mainly as fatty, lactic, sweet and cooked. The texture was identified as fatty with fatty mouthfeel, lumpy and greasy notes, and finally, the appearance was described by no uniform color and the presence of particles, exhibiting higher content in cow than in buffalo ghee.

\section{References}

Andrewes, P. (2012). Changes in Maillard reaction products in ghee during storage. Food Chemistry, 135(3), 921-928. http://dx.doi. org/10.1016/j.foodchem.2012.06.013. PMid:22953806.

Antony, B., Sharma, S., Mehta, B. M., Ratnam, K., \& Aparnathi, K. D. (2018). Study of Fourier transform near infrared (FT-NIR) spectra of ghee (anhydrous milk fat). International Journal of Dairy Technology, 71(2), 484-490. http://dx.doi.org/10.1111/1471-0307.12450.

Association of Official Analytical Chemists - AOAC. (2016). Official methods of analysis (20th ed.). Rockville: AOAC International.

Colombia, Ministerio de Salud. (1986, Febrero 24). Resolución 2310 de 1986 por la cual se reglamenta parcialmente el Título V de la Ley 09 de 1979, en lo referente a procesamiento, composición, requisitos, transporte y comercialización de los derivados lácteos. Diario Oficial. Retrieved from http://biblioteca.saludcapital.gov.co/img_upload/0 3d591f205ab80e521292987c313699c/resolucion_2310_1986.pdf

Dwivedi, C., Crosser, A. E., Mistry, V. V., \& Sharma, H. M. (2002). Effects of dietary ghee (clarified butter) on serum lipids in rats. The Journal of Applied Nutrition, 52(2-3), 65-68. http://dx.doi. org/10.4103/0974-8520.72361.

El-Shourbagy, G. A., \& El-Zahar, K. M. (2014). Oxidative stability of ghee as affected by natural antioxidants extracted from food processing wastes. Annals of Agricultural Science, 59(2), 213-220. http://dx.doi.org/10.1016/j.aoas.2014.11.008.

Esmerino, E. A., Ferraz, J. P., Tavares, E. R. Fo., Pinto, L. P. F., Freitas, M. Q., Cruz, A. G., \& Bolini, H. M. A. (2017). Consumers' perceptions toward 3 different fermented dairy products: Insights from focus groups, word association, and projective mapping. Journal of Dairy Science, 100(11), 8849-8860. http://dx.doi.org/10.3168/jds.201612533. PMid:28888609.

Ferlay, A., Bernard, L., Meynadier, A., \& Malpuech-Brugère, C. (2017). Production of trans and conjugated fatty acids in dairy ruminants and their putative effects on human health: a review. Biochimie, 141, 107-120. http://dx.doi.org/10.1016/j.biochi.2017.08.006. PMid:28804001.

Food and Agriculture Organization of the United Nations - FAO. (2013). Milk and dairy products in human nutrition. Rome: FAO. Retrieved from: http://www.fao.org/3/i3396e/i3396e.pdf

Food and Agriculture Organization of the United Nations - FAO. (2019). Food and agriculture data. Rome: FAO. Retrieved from: http://www.fao.org/faostat/en/\#compare

Ford, P. A., Jaceldo-Siegl, K., Lee, J. W., \& Tonstad, S. (2016). Trans fatty acid intake is related to emotional affect in the Adventist Health Study-2. Nutrition Research, 36(6), 509-517. http://dx.doi. org/10.1016/j.nutres.2016.01.005. PMid:27188896. 
Galvín, S., Guillén-Sans, R., Galbis, J. A., \& Guzmán-Chozas, M. (2016). Trans fatty acids in two classes of reformulated "zero trans" Spanish margarines by use of second derivative ATR-FTIR spectroscopy. Lebensmittel-Wissenschaft + Technologie, 65, 1066-1071. http:// dx.doi.org/10.1016/j.lwt.2015.09.047.

Ganguli, N. C., \& Jain, M. K. (1972). Ghee: its chemistry, processing and technology. Journal of Dairy Science, 56(1), 19-25. http://dx.doi. org/10.3168/jds.S0022-0302(73)85109-4.

Gebauer, S. K., Destaillats, F., Mouloungui, Z., Candy, L., Bezelgues, J. B., Dionisi, F., \& Baer, D. J. (2011). Effect of trans fatty acid isomers from ruminant sources on risk factors of cardiovascular disease: study design and rationale. Contemporary Clinical Trials, 32(4), 569576. http://dx.doi.org/10.1016/j.cct.2011.03.012. PMid:21458598.

Hur, S. J., Kim, H. S., Bahk, Y. Y., \& Park, Y. (2017). Overview of conjugated linoleic acid formation and accumulation in animal products. Livestock Science, 195, 105-111. http://dx.doi.org/10.1016/j. livsci.2016.11.016.

Instituto Colombiano de Normas Técnicas y Certificación - ICONTEC. (1996). NTC 3932: análisis sensorial. Identificación y selección de descriptores para establecer un perfil sensorial por una aproximación multidimensional. Bogotá, Colombia: ICONTEC.

International Organization for Standardization - ISO. (2017). ISO 6579-1: microbiology of food chain-horizontal method for detection, enumeration and serotyping of Salmonella-part 1: detection of Salmonella spp. Geneva, Switzerland: ISO.

Jakobsen, M. U., Bysted, A., Andersen, N. L., Heitmann, B. L., Hartkopp, H. B., Leth, T., Overvad, K., \& Dyerberg, J. (2006). Intake of ruminant trans fatty acids and risk of coronary heart disease: an overview. Atherosclerosis. Supplements, 7(2), 9-11. http://dx.doi.org/10.1016/j. atherosclerosissup.2006.04.004. PMid:16713389.

Koba, K., \& Yanagita, T. (2014). Health benefits of conjugated linoleic acid (CLA). Obesity Research \& Clinical Practice, 8(6), e525-e532. http://dx.doi.org/10.1016/j.orcp.2013.10.001. PMid:25434907.

Kumar, J., Das, S., \& Teoh, S. L. (2000). Dietary acrylamide and the risks of developing cancer: Facts to Ponder. Frontiers in Nutrition, 5, 1-12. http://dx.doi.org/10.3389/fnut.2018.00014. PMid:29541638.

Kwak, H. S., Meullenet, J. F., \& Lee, Y. (2016). Sensory profile, consumer acceptance and driving sensory attributes for commercial vanilla ice creams marketed in the United States. International Journal of Dairy Technology, 69(3), 346-355. http://dx.doi.org/10.1111/14710307.12314.

Liu, Z., Rochfort, S., \& Cocks, B. (2018). Milk lipidomics: what we know and what we don't. Progress in Lipid Research, 71, 70-85. http://dx.doi.org/10.1016/j.plipres.2018.06.002. PMid:29935222.

Manickavasagan, A., \& Al-Sabahi, J. N. (2014). Reduction of saturated fat in traditional foods by substitution of ghee with olive and sunflower oils: a case study with halwa. Journal of the Association of Arab Universities for Basic and Applied Sciences, 15(1), 61-67. http://dx.doi.org/10.1016/j.jaubas.2013.06.003.

Mehta, B. M., Darji, V. B., \& Aparnathi, K. D. (2015). Comparison of five analytical methods for the determination of peroxide value in oxidized ghee. Food Chemistry, 185, 449-453. http://dx.doi. org/10.1016/j.foodchem.2015.04.023. PMid:25952892.

Mozaffarian, D., Aro, A., \& Willett, W. C. (2009). Health effects of trans-fatty acids: experimental and observational evidence. European Journal of Clinical Nutrition, 63(Suppl. 2), S5-S21. http://dx.doi. org/10.1038/sj.ejcn.1602973. PMid:19424218.

Oliveira, E. W., Esmerino, E. A., Carr, B. T., Pinto, L. P. F., Silva, H. L. A., Pimentel, T. C., Bolini, H. M. A., Cruz, A. G., \& Freitas, M. Q. (2017). Reformulating Minas Frescal cheese using consumers' perceptions: Insights from intensity scales and check-all-that-apply questionnaires. Journal of Dairy Science, 100(8), 6111-6124. http:// dx.doi.org/10.3168/jds.2016-12335. PMid:28551189.
Park, Y. (2009). Conjugated linoleic acid (CLA): good or bad trans fat? Journal of Food Composition and Analysis, 22S, S4-S12. http:// dx.doi.org/10.1016/j.jfca.2008.12.002.

Pinto, V. R. A., Araújo, L. G., Soares, L. S., Dantas, M. I. S., Lucia, S. M. D., Souza, T. D., Melo, L. F., Minim, V. P. R., \& Bressan, J. (2019). Preference mapping to assess the effect of information on the acceptability of snack bars. Food Science and Technology, 39(Suppl. 1), 316-323. http://dx.doi.org/10.1590/fst.03418.

Serafeimidou, A., Zlatanos, S., Kritikos, G., \& Tourianis, A. (2013). Change of fatty acid profile, including conjugated linoleic acid (CLA) content, during refrigerated storage of yogurt made of cow and sheep milk. Journal of Food Composition and Analysis, 31(1), 24-30. http://dx.doi.org/10.1016/j.jfca.2013.02.011.

Sharma, H., Zhang, X., \& Dwivedi, C. (2010). The effect of ghee (clarified butter) on serum lipid levels and microsomal lipid peroxidation. International Quarterly Journal of Research in Ayurveda, 31(2), 134140. http://dx.doi.org/10.4103/0974-8520.72361. PMid:22131700.

Sieber, R. (2005). Oxidised cholesterol in milk and dairy products. International Dairy Journal, 15(3), 191-206. http://dx.doi.org/10.1016/j. idairyj.2004.07.013.

Silva, H. L. A., Balthazar, C. F., Silva, R., Vieira, A. H., Costa, R. G. B., Esmerino, E. A., Freitas, M. Q., \& Cruz, A. G. (2018). Sodium reduction and flavor enhancer addition in probiotic prato cheese: Contributions of quantitative descriptive analysis and temporal dominance of sensations for sensory profiling. Journal of Dairy Science, 101(10), 8837-8846. http://dx.doi.org/10.3168/jds.201814819. PMid:30077456.

Sserunjogi, M. L., Abrahamsen, R. K., \& Narvhus, J. (1998). A review paper: current knowledge of ghee and related products. International Dairy Journal, 8(8), 677-688. http://dx.doi.org/10.1016/S09586946(98)00106-X.

Stender, S., Astrup, A., \& Dyerberg, J. (2008). Ruminant and industrially produced trans fatty acids: health aspects. Food \& Nutrition Research, 52(1), 1-8. http://dx.doi.org/10.3402/fnr.v52i0.1651. PMid:19109659.

Torres, F. R., Esmerino, E. A., Carr, B. T., Ferrão, L. L., Granato, D., Pimentel, T. C., Bolini, H. M. A., Freitas, M. Q., \& Cruz, A. G. (2017). Rapid consumer-based sensory characterization of requeijão cremoso, a spreadable processed cheese: Performance of new statistical approaches to evaluate check-all-that-apply data. Journal of Dairy Science, 100(8), 6100-6110. http://dx.doi.org/10.3168/ jds.2016-12516. PMid:28571992.

Upadhyay, N., Goyal, A., Kumar, A., \& Lal, D. (2017b). Detection of adulteration by caprine body fat and mixtures of caprine body fat and groundnut oil in bovine and buffalo ghee using differential scanning calorimetry. International Journal of Dairy Technology, 70(2), 297-303. http://dx.doi.org/10.1111/1471-0307.12336.

Upadhyay, N., Kumar, A., Goyal, A., \& Lal, D. (2017a). Complete liquification time test coupled with solvent fractionation technique to detect adulteration of foreign fats in ghee. International Journal of Dairy Technology, 70(1), 110-118. http://dx.doi.org/10.1111/14710307.12323.

Vučić, V., Arsic, A., Petrovic, S., Milanovic, S., Gurinovic, M., \& Glibetic, M. (2015). Trans fatty acid content in Serbian margarines: urgent need for legislative changes and consumer information. Food Chemistry, 185, 437-440. http://dx.doi.org/10.1016/j.foodchem.2015.04.018. PMid:25952890.

Yang, B., Chen, H., Stanton, C., Ross, R. P., Zhang, H., Chen, Y. Q., \& Chen, W. (2015). Review of the roles of conjugated linoleic acid in health and disease. Journal of Functional Foods, 15, 314-325. http:// dx.doi.org/10.1016/j.jff.2015.03.050. 